\title{
Actualizing Blue Economy: Multi-Track Diplomacy in Supporting Indonesia - Philippines Ocean Economy Cooperation (2014-2017)
}

\author{
Yossica Novyanti Lyonitha Putri ${ }^{1}$ \\ International Relations Study Program, Faculty of Humanities ${ }^{1}$ \\ President University, Jababeka ${ }^{1}$ \\ yossicapt@gmail.com ${ }^{1}$ \\ Anggara Raharyo ${ }^{2}$ \\ International Relations Study Program, Faculty of Humanities ${ }^{2}$ \\ President University, Jababeka² \\ anggara.raharyo@president.ac.id ${ }^{2}$
}

\begin{abstract}
ABSTRAK
Artikel ini bertujuan untuk menganalisis strategi diplomasi Indonesia ke Filipina dalam mengaktualisasikan ekonomi biru dari 2014 hingga 2017. Kondisi geografis Indonesia, yang merupakan negara kepulauan terbesar di dunia dan terletak di dalam kawasan segitiga karang menganugerahkan Indonesia dengan potensi laut yang sangat besar dan valuasi tinggi. Indonesia pada masa pemerintahan Presiden Joko Widodo berkomitmen untuk mengembangkan ekonomi mereka dari sektor kelautan menggunakan prinsip ekonomi biru-- pemanfaatan potensi kelautan dengan mempertimbangkan perhitungan jangka panjang antara keberlanjutan sosial dan lingkungan. Penulis menggunakan teori 'complex interdependence' yang menunjukkan bahwa kerja sama antara Indonesia dan Filipina dengan melibatkan peran organisasi non-pemerintah dan pemangku kepentingan bisnis berkontribusi untuk memecahkan masalah dan mendukung keberhasilan implementasi ekonomi biru.Menggunakan metodologi penelitian kualitatif, skripsi ini menjelaskan strategi diplomasi Indonesia dalam upaya untuk mengaktualisasikan ekonomi bitu dengan menggunakan langkah Multi-track Diplomacy, dengan fokus dalam kerjasama negara (Track I) melalui penandatanganan Joint Declaration of Sea Connectivity antara kedua negara, organisasi non-pemerintah (Track II) melalui penetapan kelompok kerja untuk kerjasama Coral Triangle Initiative dengan melibatkan organisasi nonpemerintah di Indonesia, dan bisnis (Track III) melalui Forum Bisnis Regional Coral Triangle Initiatives kepada Filipina selama masa administrasi Presiden Joko Widodo tahun 2014-2017.
\end{abstract}


Kata kunci: Ekonomi Biru, Kerjasama, Multi-Track Diplomacy, Indonesia-Filipina

\begin{abstract}
This article aims to analyze Indonesia's diplomacy strategy to the Philippines in actualizing blue economy from 2014 until 2017. Indonesia's geographical condition, which is the largest archipelagic country in the world and is located within the coral triangle region brace Indonesia to have enormous marine potentials and high valuation. Indonesia during the reign of President Joko Widodo committed to developing their economy from the marine sector using blue economic principle-- the utilization of marine potential by considering the long-term calculation between social and environmental sustainability. The authors use complex interdependence theory which shows that cooperation between Indonesia and the Philippines by involving the role of non-governmental organizations and business stakeholders contributes to solve problems and support the successful implementation of the blue economy. Through a qualitative analytic research method, this article finds Indonesia's diplomacy strategy as the effort to implement blue economy by using Multi-track Diplomacy approach, which focuses on the government (Track I) through the signing of Joint Declaration of Sea Connectivity between the two countries, non-government professional (Track II) through the establishment of the Working Group for Coral Triangle Initiatives involving Non-Governmental Organizations in Indonesia, and business (Track III) through the Coral Triangle Initiatives-Business Forum to the Philippines during the administration of President Joko Widodo in 2014-2017.
\end{abstract}

Keywords: Blue Economy, Cooperation, Multi-Track Diplomacy, IndonesiaPhilippines

\title{
1. Introduction
}

The given condition of the Indonesian sea which surrounded by the Indian Ocean and the Pacific Ocean with $290.000 \mathrm{~km}^{2}$ territorial sea area, has the second-longest coastline in the world with the total length of $108.000 \mathrm{~km}, 3.110 .000 \mathrm{~km}$ the total area of inland waters, and 2,8 million $\mathrm{km}^{2}$ total areas belong to Indonesian Exclusive Economic Zone (Badan Informasi Geospasial, n.d.) provides a tremendous opportunity for its prosper geopolitics and geostrategic cooperation. Indonesia's marine area also occupies $65 \%$ of the total area in the Coral Triangle region-along with Malaysia, Philippines, East Timor, Papua New Guinea, the Solomon Islandshas the largest coral reefs area in Southeast Asia, where more than 600 species of coral reefs in which cover $75 \%$ of the total coral reefs species in the world (Asian 
Development Bank, 2014, p. 5). The potential income generated from marine resources according to former Minister of Maritime Affairs and Fisheries Sharif C. Sutardjo, is estimated to reach 171 billion US\$ per year (Kompas, 2014). Joko Widodo's Global Maritime Fulcrum grand vision reveals Indonesia's emphasis on the development of the maritime sector in various aspects during his respective administration, including upstreaming sustainable maritime economic development. This firm commitment is increasingly getting, even more, prompting with the ratification of Indonesian Ocean Policy through Presidential Regulation No. 16 of 2017, Article 2 which consist of the Indonesian Ocean Policy National Document and the Indonesian Ocean Policy Action Plan, in which policy will be used as a guideline for ministries and government agencies in implementing public and foreign policies, as well as being a reference for the public and business stakeholders to participate in the success of Indonesia's maritime development vision (Sekretariat Kabinet Republik Indonesia, 2017). Moreover, the direction of Indonesia's economic development by considering the weight of sustainability aspects has also been mentioned in the Law No. 32 of 2014 regarding maritime affairs, article 14 (1) explains that the utilization and exploitation of marine resources will precisely be using blue economy principles:

"Pemerintah dan Pemerintah Daerah sesuai dengan kewenangannya melakukan pengelolaan kelautan untuk sebesar-besarnya kemakmuran rakyat melalui pemanfaatakan dan pengusahaan sumber daya kelautan dengan menggunakan prinsip ekonomi biru." (Law No. 32 of 2014 Article 14)

According to mentioned law above, Indonesian Law No. 32 of 2014 article 14 (1) states that the central and local government are in accordance with their authority to conduct marine management for the greatest prosperity of the people through the utilization and exploitation of marine resources using blue economic principles. To stimulate the maximization of Indonesia's marine potential, Indonesian government is committed to strengthening the intensity of maritime diplomacy activities which also involving the non-state actors to support the achievement of its national interests (Kementrian Luar Negeri Republik Indonesia, 2014). 


\section{The Notion of the Blue Economy}

Blue economy offers an economic management method in which maximizing income can be directly proportional to the sustainability of nature. This idea was first put forward into a concept in 2010 by Gunter Pauli, a professor, entrepreneur, and founder of the Zero Emission Research Initiative (ZERI). Gunter Pauli himself emphasizes that environmentally friendly innovation and technological development as well as zero waste to utilize sustainable natural resources and increase employment opportunities (Pauli, 2010, p. 75). The exertion of local resources with efficient and environmentally friendly innovations will as much as possible provide added value for economic improvement, quality of human life, job creation, and saving resources so that the benefits can be obtained longer. Gunter Pauli elucidates that blue economy is an economic system that embraces innovation in utilizing natural resources productively and efficiently so there will be no waste and emissions but greater economic growth and enhance job fields (Ibid, p.17).

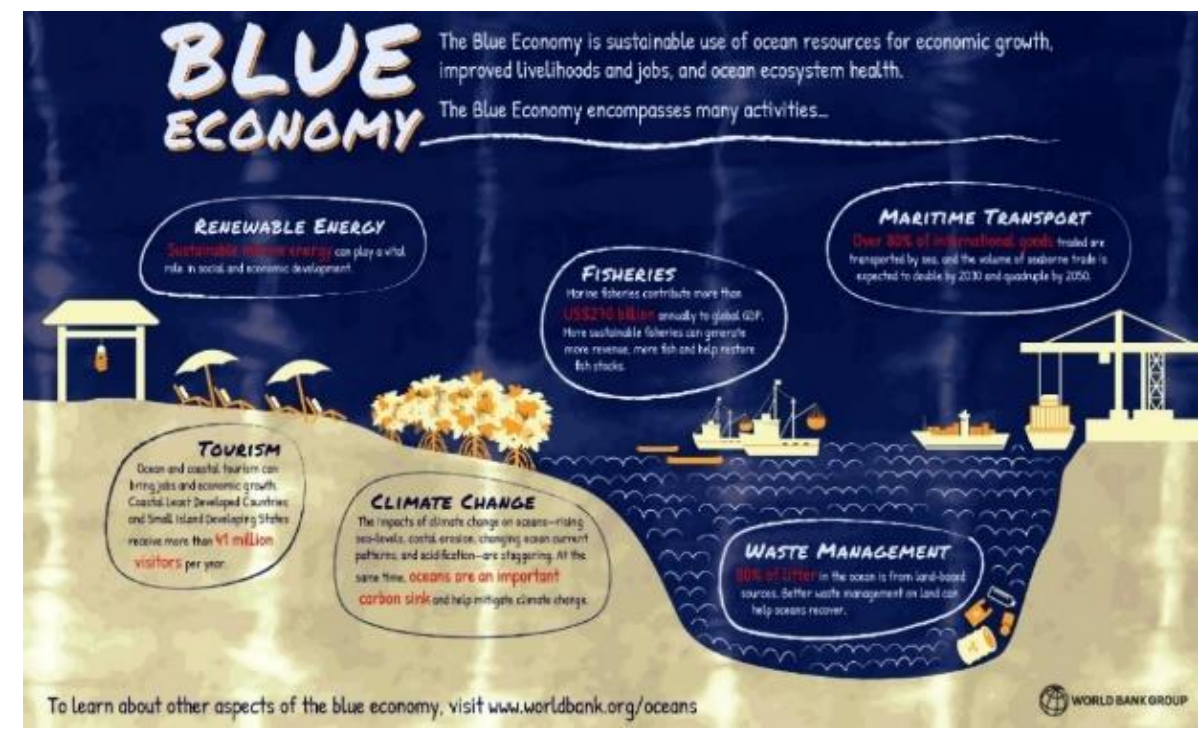

Figure 1. Blue Economy Infographic (Retrieved from worldbank.org, accessed January 15, 2019)

Notwithstanding that this concept has developed and attracted the attention of many economists and policymakers over the past decade, the official definition of the terminology of 'blue economy' has not been set yet. World Bank in its publication The Potential of Blue Economy interprets the concept as follows: "The 'blue economy' concept seeks to promote economic growth, social inclusion, and the preservation or improvement of livelihoods while at the same time ensuring environmental sustainability of the oceans and coastal areas." (World Bank and United Nations Department of Economic and Social Affairs, 2017, p. 1) 
The blue economy is explained in Indonesian Law No. 32 of 2014, under the explanation of Article 14 (1):

"Yang dimaksud dengan 'ekonomi biru' adalah sebuah pendekatan untuk meningkatkan pengelolaan kelautan berkelanjutan serta konservasi laut dan sumber daya pesisir beserta ekosistemnya dalam rangka mewujudkan pertumbuhan ekonomi dengan prinsip-prinsip antara lain keterlibatan masyarakat, efisiensi sumber daya, meminimalkan limbah, dan nilai tambah ganda (multiple revenue)." (Indonesian Law No. 32 2014)

The law refers to blue economy as the approach to intensify economic development through marine resources utilization and conservation in a sustainable manner, by involving the society and highlighting zero waste. To put these ideas in a nutshell, one common interpretation of the blue economy is maximizing economic value of marine potential with sustainable approach to acquire greater and longer-term results.

World Wildlife Fund for Nature (WWF) then published a guideline entitled Principles for a Sustainable Blue Economy which contained absolute principles in the blue economy concept. The report highlight the points of balance long-term economy and environmental benefits; marine ecosystem production-friendly; clean and renewable technology, innovative and proactive; involving public and private sectors (World Wide Fund for Nature, 2015, p. 1-6).

Essentially, the blue economy is the utilization of marine potential by considering ecological sustainability aspects such as environment and social, thus efficient management is emphasized in order that these resources can be used optimally (See Table 1).

The condition that $72 \%$ of the earth's total surface is the ocean makes the implementation of the blue economy globally is respected as necessary. The blue economy is prominent to reckon the increasing global population will automatically increasing the demanding needs. Besides, the sea serves as one of the substantial food sources providers and regulates the earth's climate and temperature so that its sustainability needs to be nurtured. 


\begin{tabular}{|c|c|c|c|}
\hline \multicolumn{4}{|c|}{ Components of the Blue Economy } \\
\hline $\begin{array}{l}\text { Type of } \\
\text { Activity }\end{array}$ & Ocean Service & Industry & Drivers of Growth \\
\hline \multirow{3}{*}{$\begin{array}{l}\text { Harvest of } \\
\text { living } \\
\text { resources }\end{array}$} & Seafood & Fisheries & Food security \\
\hline & $\begin{array}{l}\text { Marine } \\
\text { biotechnology }\end{array}$ & Aquaculture & $\begin{array}{l}\text { Demand for protein } \\
\text { consumption }\end{array}$ \\
\hline & & $\begin{array}{l}\text { Pharmaceuticals, } \\
\text { chemical }\end{array}$ & $\begin{array}{l}\text { R\&D healthcare and } \\
\text { industry }\end{array}$ \\
\hline \multirow{4}{*}{$\begin{array}{l}\text { Extraction } \\
\text { of non- } \\
\text { living } \\
\text { resources }\end{array}$} & Minerals & Seabed mining & Demand for minerals \\
\hline & \multirow[t]{2}{*}{ Energy } & Oil and gas & \multirow{2}{*}{$\begin{array}{l}\text { Demand for energy } \\
\text { sources }\end{array}$} \\
\hline & & Renewable & \\
\hline & Freshwater & Desalination & $\begin{array}{l}\text { Demand for } \\
\text { freshwater necessity }\end{array}$ \\
\hline \multirow{4}{*}{$\begin{array}{l}\text { Commerce } \\
\text { and trade }\end{array}$} & \multirow{2}{*}{$\begin{array}{l}\text { Transportation } \\
\text { and trade }\end{array}$} & Shipping & \multirow{2}{*}{$\begin{array}{l}\text { Growth in seaborne } \\
\text { trade/international } \\
\text { regulations }\end{array}$} \\
\hline & & $\begin{array}{l}\text { Port } \\
\text { infrastructure } \\
\text { and service }\end{array}$ & \\
\hline & \multirow[t]{2}{*}{$\begin{array}{l}\text { Tourism and } \\
\text { recreation }\end{array}$} & Tourism & $\begin{array}{l}\text { Growth of global } \\
\text { tourism }\end{array}$ \\
\hline & & $\begin{array}{l}\text { Coastal } \\
\text { development }\end{array}$ & $\begin{array}{l}\text { Coastal } \\
\text { urbanization/domestic } \\
\text { regulations }\end{array}$ \\
\hline \multirow[t]{4}{*}{$\begin{array}{l}\text { Response } \\
\text { to the } \\
\text { oceans } \\
\text { health } \\
\text { challenge }\end{array}$} & $\begin{array}{l}\text { Ocean } \\
\text { monitoring } \\
\text { and } \\
\text { surveillance }\end{array}$ & $\begin{array}{l}\text { Technology and } \\
\text { R\&D }\end{array}$ & $\begin{array}{l}\text { R\&D in ocean } \\
\text { technology }\end{array}$ \\
\hline & $\begin{array}{l}\text { Carbon } \\
\text { sequestration }\end{array}$ & Blue carbon & \multirow{3}{*}{$\begin{array}{l}\text { Growth in coastal, } \\
\text { ocean protection, } \\
\text { conservation activities }\end{array}$} \\
\hline & $\begin{array}{l}\text { Coastal } \\
\text { protection }\end{array}$ & $\begin{array}{l}\text { Habitat } \\
\text { protection and } \\
\text { restoration }\end{array}$ & \\
\hline & $\begin{array}{l}\text { Waste } \\
\text { disposal }\end{array}$ & $\begin{array}{l}\text { Assimilation for } \\
\text { nutrients and } \\
\text { wastes }\end{array}$ & \\
\hline
\end{tabular}

Table 1. Components of the blue economy (Source: OECD, The Ocean Economy in 2030, p. 20

\section{Indonesia on Ocean-based Economy}

In a report by OECD reveals that the ocean-based economic industry contributed $2,5 \%$ of world gross value added (GVA) or equivalent to US $\$ 1.5$ trillion on 2010 and predicted to continue increasing up to 3 trillion by 2030 (Organisation for Economic Cooperation and Development, 2016, p. 7). In addition, more than 350 million jobs worldwide are linked to marine sector, around 60 million people are working in fisheries and aquaculture sector and 171 million tons of fish are produced every year (FAO by United Nations, 2018, p. 25). By estimation from reports above show that the ocean contributes up to 6 trillion US\$ to the world economy, and thus, if the 
ocean were a country, it will become the seventh country with the largest income in the world (Organisation for Economic Cooperation and Development, 2016, p. 11). To consider that $90 \%$ of world trade activities are transported using ships, economic growth is considerably linked to the sea transportation activities (United Nations Conference on Trade and Development, 2015, p. 7). Furthermore, World Bank predicts that the ocean will become a robust economic force this century (World Bank, 2016, p. 24).

Indonesia as the biggest archipelagic country in the world has enormous potential as marine sectors can provide fisheries sector, marine tourism, renewable energy, seabed minerals, oil and gas, shipping, maritime industry, marine transportation lines, which are estimated to reach US\$ 171 billion per year (Kompas, 2014). The geographical location of Indonesia in the Coral Triangle region covers $56 \%$ coral triangle reefs area as well as $18 \%$ of the world, with $75 \%$ of the total coral species and 2057 species of coral fish are within Indonesia concluding it as a country with mega-biodiversity (Asian Development Bank, 2014, p. 4-6). Following the facts, Indonesia's fishing activities have significant potential for the country's economy. The report in The State of World Fisheries and Aquaculture 2018, shows that Indonesia is the second-largest capture fish producer after China for more than 10 years (FAO by United Nations, 2018, p. 71). The report also revealed that 171 million tonnes of global fisheries in 2016 and Indonesia contributed $6.2 \%$ in total. In addition, $40 \%$ of the $90 \%$ of world trade routes pass through Indonesian waters (Kementerian Perhubungan Republik Indonesia, 2018).

\section{Indonesia to the Philippines: Cooperation for The Long-term Goals}

Located in the Southeast Asia region and has the same geographic features, the Philippines is a strategic partner in Indonesia's bilateral cooperation relations. Having the same background as an archipelagic with vast seas, two countries have immensely great prospects for the implementation of the blue economy concept.

The Philippines is an archipelagic country in the Southeast Asia region which consists of approximately 7,641 islands and bordered by the Sulawesi Sea to Indonesia (The Central Mapping Agency of the Government of the Philippines, n.d.). The geographical conditions of a country are one of the salient factors in determining cooperation activity. (Suradinata, 2011, p. 80-81). The geographical aspect itself has the link to the other country, both land and sea boundaries. Geographical proximity has created opportunities as well as challenges to cross national borders, therefore, it requires collaborative efforts to accelerate the desired goals and suppress the worst possibilities in a diplomatic relationship.

Indonesia and the Philippines are one of the members of the Association of Southeast 
Asian Nations (ASEAN) and sub-regional cooperation Brunei-Indonesia-PhilippinesMalaysia East ASEAN Growth Area (BIMP-EAGA). This indicates that the two countries tend to make collaborative efforts primarily in developing the country's economy. Trade and commerce sector, including export and import activities is one manifestation of bilateral cooperation between Indonesia and the Philippines which has long been the economic activity of the two states. The Philippines is one of the important partners of Indonesia's export-import activities, as it became the fourth largest Indonesia's export destination in the last decade. (Badan Pusat Statistik, 2014). The total trade value of Indonesia and the Philippines in the 2012-2016 period has a positive trend value of $6.24 \%$, which means there has been a trade surplus for exports to the Philippines in that period (Kementerian Perdagangan RI, 2017, p. 1). The total Philippine foreign trade in January-April 2014 period reached to 40.45 US\$ billion, gotten up by $13.31 \%$ from the previous period (Kementerian Perdagangan Republik Indonesia, 2014, p. 1).

When the coral triangle region stores $53 \%$ of the total coral species in the world, (Asian Development Bank, 2014, p. 5) likewise, it has the social ties of each country within the coral triangle region area, thus conservation initiative on the coral triangle area was formed to guard this region against various threats from human activities and global climate change. From the economic potential and level of dependence from people of each country, the countries in the coral reef triangle area try to follow up on the existing problems and strive to resolve problems in the region. 


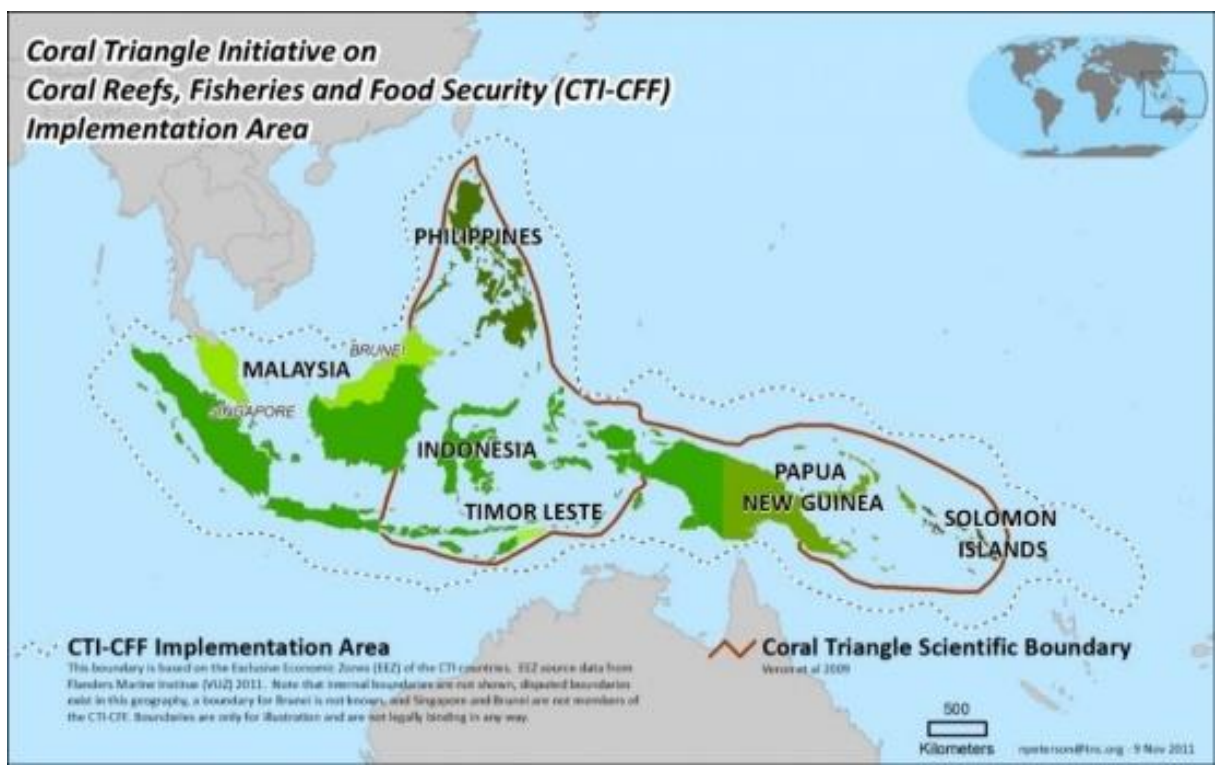

Figure 2. Coral Triangle Initiative Implementation Area (Source: coraltriangleinitiative.org, accessed on January 10, 2019)

Established on 2007, The Coral Triangle Initiative (CTI) is a multilateral commitment of Indonesia, the Philippines, Malaysia, Solomon Islands, Papua New Guinea, and Timor Leste (or called CT6), supported by international environmental organizations that are World Wildlife Fund (WWF), Conservation International (CI), and The Nature Conservancy (TNC) and has the support of international funding commitments, especially from the United States and Australia as well as World Bank, Asian Development Bank and the Global Environment Facility (GEF) (Coral Triangle Initiative On Coral Reefs, Fisheries, and Food Security, 2015). CTI has committed to the Regional Plan of Action (RPOA), a voluntary strategic action plan that is divided into several working groups that address issues that are the focus of the CTI-CFF regarding the empowerment of marine ecosystems, such as i. Seascapes management; ii. Ecosystem-based fisheries management; iii. Marine protected area; iv. Climate change adaptation and; v. endangered marine species. (Coral Triangle Initiative on Coral Reefs, Fisheries, and Food Security, 2009, p. 11-49). From the designated RPOA, it then derived into the National Plan of Action (NPOA) of each member country that has been adjusted to each country's needs but reflects the integrity of the RPOA.

\section{Challenges in Implementing Blue Economy}

Historically, Indonesia's interest in the blue economic concept was firstly conveyed by former president Susilo Bambang Yudhoyono at the Rio+ 20 Forum in 2012 which focused on marine management and coastal resources. (Kementerian Kelautan dan Perikanan, 2012, p. 2). During the occasion, he expressed the beginning of Indonesia's development projection towards blue economy: "For Indonesia, Blue Economy is our next frontier" (Ibid.) 
Vice President Jusuf Kalla addressing Indonesia's efforts in implementing blue economy are projected to marine resources, maritime diplomacy, infrastructure and sea connectivity, marine culture and marine security (Kementerian Luar Negeri Republik Indonesia, 2016). However, substantively, the inversely distinct condition in the field become substantial challenges towards Indonesia's assertive mission in implementing the blue economy is rather alarming.

Findings from Jambeck Research Group found that every year, up to 12.7 million metric tonnes of plastic waste is generated from the land to the ocean or $80 \%$ from the total waste and Indonesia is placing as the second top country that contributing $10.1 \%$ from the total, followed by the Philippines who contribute $5.9 \%$ from the total (Jambeck et al., 2015, p. 769). Without solving waste management, the waste volume gets worse by 2025 where the world will experience a plastic waste emergency (Ibid.)

The Reefs at Risk Revisited report shows that the biggest threat to coral reefs in the Coral Triangle countries such as Indonesia, Malaysia, Papua New Guinea, the Philippines, Solomon Islands, and Timor Leste are overfishing, water pollution and coastal development (Burke, Reytar, Spalding, \& Perry, 2011). The ocean waste pollution is not solely having a terrible impact on the environment, but also has a detrimental effect on economic point due to the state revenues from the marine sector will also decreasing. United Nations Environment Programme (UNEP) explains marine plastic debris threats will greatly affect economic and social activities, such as fishing, aquaculture, shipping, tourism and recreation (United Nations Environment Programme and GRID-Arendal, 2016, p. 18). In an interview, Maritime Coordinating Minister Luhut Binsar Pandjaitan said that state losses due to plastic waste can reach up to US\$1.2 billion (National Geographic Indonesia, 2017).

In developing Indonesia's marine economy, the principle of the blue economy emphasizes long-term practice on social and environmental aspects. Yet, in paving the way to the state of blue economy, Indonesia is facing significant challenges such as the utilization of resources management that have not been maximized; the potential of the fishing industry, marine tourism, and trade. To maximize this potential, problems regarding unsustainable fishing practices, marine infrastructure, and marine tourism management need to be resolved, especially the problem of marine waste that will affect the aforementioned three sectors. Having the adjoin geographical state and bordered by the sea, the finding on marine plastic debris that becomes the world concerns which take Indonesia as the second-largest contributor, followed by the Philippines in the third place, rendering the substantial issue which can disrupt and hamper the economic and the sea conditions of both countries. Environmental issues, especially the issue of the sea and all the ecosystems in it, cannot be solved by only one country. 


\section{Actualizing Blue Economy: Multi-Track Diplomacy in Supporting Indonesia - Philippine Ocean Economy Cooperation}

The dynamics of global politics have enlarged the diplomatic activities possible through various approaches; economic, technology, cultural, sports and involving non-state actors with a significant level of role. In this context, the Indonesian government recognizes the role of non-state actors in foreign policy to support the achievement of its national interests (Kementerian Luar Negeri Republik Indonesia, 2014). This phenomenon at a time shows the existence of a strategy organized by Indonesian government which began to involve the non-state actors to achieve its interest in conveying the understanding to another state in order to avoid conflict for the sake of maintaining stability and peace.

Indonesia's commitment to realizing national economic development through the concept of a blue economy has been strengthened through the Law of the Sea No. 32 of 2014 and the Indonesian Ocean Policy, which also involving related stakeholders, such as the community and the business sector. In implementing its foreign policy, a state needs a system, tools and supporting actors to achieve maximum results, in line with the objectives of the policy itself. The nongovernmental organization which has attracted the attention of some political science scholars owns the capability to voice, engage with the psychological approach, and go beyond state borders (Diamond \& McDonald, 1996, p. 40).

In implementing a blue economy, Indonesia is facing economic and social challenges. The geographical conditions of Indonesia where its sea areas are adjacent to Philippines sea area allow gravitating cooperation efforts from both parties. Besides, the fact that the Philippines is the third-largest contributor to marine waste in the world can also worsen Indonesia's marine conditions (Jambeck et al., 2015, p. 769). The interdependence complex sees that actions or changes in one party will affect several things related to the achievement or desired needs of the other. Cooperation between countries in complex interdependence conditions indicates that they have common goals and common intended results, which will lead to prosperity and stability (Ibid.)

This article sees that Indonesia recognizes the role of non-state actors in achieving its national interests, which then are developed by the author, in theory, using multitrack diplomacy. The research which focuses on three tracks on Multi-Track Diplomacy (Track I, Track II, Track III) found that as the effort to implementing the blue economy, the Indonesian government implemented Multi-track Diplomacy strategy involving the government, non-government organizations, and business forum in realizing the blue economy from 2014-2017: 


\subsection{Track III: CTI-CFF Regional Business Forum (2015)}

In 2015, the fourth CTI-CFF Regional Business Forum was held in Nusa Dua, Bali on 27-29 August, turning Indonesia as the host for the second time. In collaboration with the CTI-CFF, the Indonesian government seeks its diplomatic mission to actualize the blue economy through a Business Forum that invites company stakeholders and entrepreneurs to join their ideas to promote the implementation of blue economy to the roundtables, brings together not only funding partners and interest groups but also business economic partners to offer environmentally friendly investments in the Coral Triangle region. To note, Diamond and McDonald see business activities, especially in commerce, have paved the way to build relationships and understanding as the starter for joint cooperation (Diamond \& McDonald, 1996, p. 52). This forum can be a channel of discussion for businesspeople from Indonesia and businesspeople from the Philippines to improve sustainable economic cooperation that does not damage the environment, and alleviate any possible conflict that is a challenge in the implementation of the blue economy. On the other side, business approach likewise is an opportunity to provide campaign and awareness to the community as well as to fellow business players through discussion or exchange ideas. The 3P scheme (People, Profit, Planet) approach can be applied.

\subsection{Track II: The Establishment of Indonesia CTI-CFF Expertise and Working Group (2016)}

To support the implementation of activities related to the Indonesian CTI NPOA and RPOA was manifested through Presidential Regulation No. 85 of 2015. This Presidential Regulation states that this National Committee consists of the Secretariat of the Indonesia CTI-CFF National Committee, Working Groups, and experts. Through Coordinating Minister for Maritime and Natural Resources Decree No. 9 of 2016, signed on 31 March 2016, as well as the chair of the Indonesian CTI-CFF national committee formed the Secretariat of the Indonesian CTI-CFF National Committee consisting of the Secretariat, Working Groups and Expert Groups with membership arrangements from relevant government agencies along with the position in the team and job description that has been set. According to the decree, the expert group has the main task as follows:

1. Provide input to the chairman of the Secretary of the National Committee of the CTI-CFF Indonesia whether requested or not;

2. Make regular scientific studies of related important documents;

3. Facilitating periodic scientific meetings;

4. Conduct studies for national, regional and international policy inputs;

5. Facilitating scientific publications about CTI-CFF (Coordinating Minister for Maritime and Natural Resources Decree No. 9 of 2016). 
This working group involves non-governmental organizations such as WWF Indonesia, CI Indonesia, TNC Indonesia, Coral Triangle Center, RARE Indonesia, and some academicians. The Decree of the Director-General of Sea Space Management No. 27 of 2016 shows in detail the division of members from each working group involved. These respective non-governmental organizations have been actively working to conserve Indonesia's natural resources and species. Especially for WWF Indonesia, TNC Indonesia, CI Indonesia, they have jointly supported CTI-CFF programs from the beginning were formed as founding partners. They have voice, knowledge, psychological approachability, and most importantly, able to go beyond state boundaries. Keohane and Nye in Power and Interdependence: World Politics in Transition describe the characteristics under complex interdependence conditions, in which one of them, including the dominant instruments in multiple channels of diplomatic interaction; the considerably involvement of non-state actors such as nongovernmental organization (NGO), transnational organizations, multinational corporation (MNC), scientist (Keohane \& Nye, 1977, p. 26).

The popularity of NGOs as one of the actors in international relations has attracted the attention of some political science scholars. NGO's journey in the world forum explains that their presence has been taken into account, recognizing that they have valid organizational and research management capabilities. At the same time, the NGO itself has the capability to do work that is not achieved by the government, which is often referred to as 'government's right hand' because it can include jobs that cannot be fulfilled by the government and its ability to support the success of the government agenda (Rajasekhar \& Biradar, 2004, p. 166). NGOs have played a substantial political role in providing stability within cross-national societies, by delivering socio-economic assistance to the tiny sectors that were unreachable by the government, by providing direct linkages between governments and local or foreign communities (U.S. Department of State, 2006). Moreover, NGOs have human resources that can support government policies, such as the scientists or activists who directly take and expertise of the field.

\subsection{Track I: The Signing of Joint Declaration on The Establishment of Sea Connectivity Between Davao/General Santos, Southern Mindanao and Bitung, South Sulawesi (2017)}

On April $28^{\text {th }}$ 2017, Minister of Transportation of the Republic of Indonesia Budi Karya Sumadi and Secretary of Transportation of the Philippines Arthur P. Tugade signed a Joint Declaration on Indonesia-Philippines Sea Connectivity using the BitungDavao/General Santos Roll-on Roll-Off (RoRo) Routes during the $12^{\text {th }}$ Brunei, Indonesia, Malaysia, and Philippines - East ASEAN Growth Area (BIMP-EAGA) Summit in Manila, Philippines (Kementerian Perhubungan Republik Indonesia, 2017). Witnessed by the President of the Republic of Indonesia Joko Widodo and Philippine President Rodrigo Duterte, also accompanied by the Minister of Foreign Affairs of the Republic of Indonesia Retno Marsudi, the signing was a follow-up of the BIMP-EAGA meeting of the Sea Linkages Working Group in Manado from 19-20 April 2017 before discussing the importance mutually beneficial cooperation in increasing sea 
transportation as an economic acceleration especially for BIMP-EAGA members (Kementerian Perhubungan Republik Indonesia, 2017).

Refer to the official document, below are the Joint Declaration on The Establishment of Sea Connectivity Between Davao/General Santos, Southern Mindanao and Bitung, South Sulawesi as follows:

1. The establishment of the Davao/General Santos, the Philippines and Bitung, Indonesia aims to boost physical infrastructure development, strengthen effective institutional arrangements and empower people-to-people interactions between Indonesia and the Philippines;

2. Both Governments declare as follows:

a. To encourage the establishment of direct sea connectivity between Davao/General Santos, Southern Mindanao, the Philippines and Bitung, North Sulawesi, Indonesia;

b. To consider designating Davao/General Santos Port in Southern Mindanao, the Philippines and Bitung Port in North Sulawesi, Indonesia as the designated Ports under this declaration;

c. To consult each other regularly to ensure the full implementation of the establishment of the aforementioned sea connectivity; and

d. To look into the establishment of a mechanism and/or instruct officials to undertake measures to ensure that sea connectivity services, including but not limited to, RORO shipping services, meet the safety, security and environmental protection standards set by relevant international conventions. (Ministry of Foreign Affair of the Republic of Indonesia, 2017)

The connectivity route of the Bitung-Davao/General Santos, which was officially launched by each head of state on April $30^{\text {th }}, 2017$, is planned to encourage trade activities between the two countries (Tejano, 2017). Beforehand, the shipping line had to first go through Jakarta or Manila, but this new direct route is allowing the shipping service route to pass directly from Bitung to Davao or General Santos using the RoRo fast ship with a travel time of around 2.5 days which the previous condition took them up to 5 weeks (Sekretariat Kabinet Republik Indonesia, 2017).

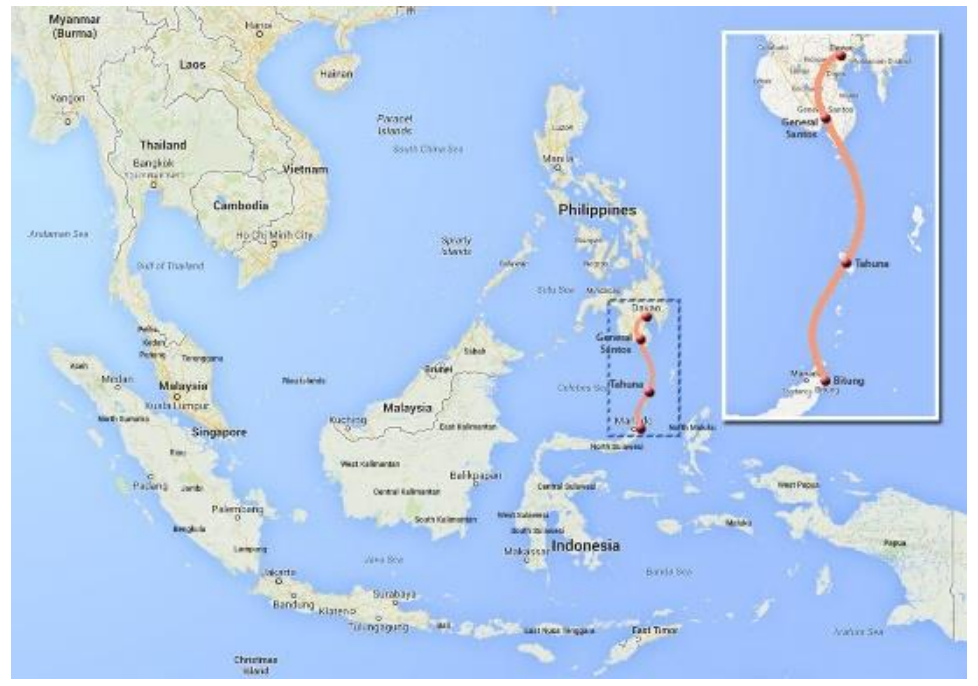


Figure 3. Ro-Ro Trade Shipping Route (Retrieved from http://minda.gov.ph/, accessed on January 10, 2019)

The signing of the Joint Declaration on the Establishment of Sea Connectivity between Davao/General Santos, Southern Mindanao and Bitung, South Sulawesi is one of the efforts conducted by the Indonesian government in government-to-government level, or diplomacy track I to implement blue economy through cooperation in sea connectivity, also indicates the government-to-government process that seeks to establish, manage and improve foreign relations to increase trust, mediation, and conflict resolution, prevent violence, and achieve national interests through a formal process through the head of state or official government institution (Diamond \& McDonald, 1996, p. xx). Through the opening of the Super Shuttle Ro-Ro shipping line, it is expected to be able to enhance Indonesia's economic potential by boosting the trade activity and as a bigger opportunity to open the market to the Philippines.

\section{Conclusion}

The concern towards the stability of sea conditions has begun to rise to the surface of the Indonesian government's interest in over the past half-decade. Ocean economy development is a concern within President Joko Widodo's administration development agenda. However, marine natural resource extraction activities pose a threat to marine health conditions and the guarantee of resources available for humans. Sustainability issues are at the center of table in the blue economy concept, which emphasizes efficient and effective sustainable business practices, taking into account environmental sustainability. This commitment was then looked at by the Indonesian government to be implemented, see the prospect of a huge valuation of the Indonesian marine areas. The blue economy activities cover fisheries, marine tourism, infrastructure, and sea lanes, renewable energy, and sea-mining. The issue in the thesis focus on the prospect of fisheries, marine tourism, and sea lanes utilization.

The blue economy which is a voluntary commitment requires support from all stakeholders in Indonesia. Some issues need to be improved or resolved, through cooperation to achieve the national interests. Indonesia has actively promoted blue economy in international and national forums. In the motion of issues within the scope of the blue economy, essentially Indonesia and the Philippines have common issues and common goals such as the geographical conditions of the archipelagic country, marine pollution problems, and economic development. The issues in the blue economy are also the concern for non-governmental environmental-based organizations' works because the principles of sustainability support their mission to maintain environmental balance with human activities. The involvement of business actors in the blue economy further strengthens the efforts to deliver understanding and actualization of increasing environmentally friendly business activities. WWF Indonesia, CI Indonesia, TNC Indonesia which have been involved in the implementation of the CTI-CFF work program have human resources to conduct scientific studies and social approaches to local communities, and their status as transnational organizations allows them to convey influence and messages and go 
beyond boundaries. These patterns likewise happen in the CTI Regional Business Forum which becomes the space for local business players to Multinational Corporations (MNCs) to exchange ideas and increase investment activities.

In this matter, the blue economy directly or indirectly requires the Indonesian government and all actors who have an important role in the success of the blue economy and the issues within to continue to carry out various cooperative relationships and various diplomatic strategies or in totality known as Multi-Track Diplomacy. Multi-Track Diplomacy provides more opportunities and influence in the activities of Indonesia's efforts in implementing the blue economy concept because it creates peacebuilding through soft power using the role of non-government and business through collaboration with the Philippines. It respectively shows that diplomacy is no longer solely a government-to-government relationship, but has involved various scopes and issues so as to create stronger influences, reaching work that the government has not touched as an extension of hand, generating more creative ideas, expanding international friendship relations, and strategy efficiency in realizing peace-based cooperative relations. All their works are in accordance with and in favour of the government. The article found that in implementing the blue economy, the Indonesian government implemented a Multi-track Diplomacy strategy involving the government (Track I), with the study case of the signing of the Joint Declaration of Sea Connectivity between the two countries, non-government professional (Track II) through the establishment of the Working Group for Coral Triangle Initiatives involving Non-Governmental Organizations in Indonesia, and business (Track III) through the Coral Triangle Initiatives-Business Forum.

\section{References}

\section{Books}

Diamond, L., \& McDonald, J. (1996). Multi-Track Diplomacy: A Systems Approach to Peace. New York: Kumarian Press.

Keohane, R. O., \& Nye, J. S. (1977). Power and Interdependence: World Politics in Transition. Boston: Little Brown.

Pauli, G. (2010). The Blue Economy-10 Years, 100 Innovations, 100 Million Jobs. Taos: Paradigm Publications.

Rajasekhar, D., \& Biradar, R. R. (2004). Reluctant Partners Coming Together?: Interface Between People, Government, and the NGOs. New Delhi: Concept Publishing Company.

World Bank and United Nations Department of Economic and Social Affairs. (2017). The Potential of the Blue Economy: Increasing Long-term Benefits of the 
Sustainable Use of Marine Resources for Small Island Developing States and Coastal Least Developed Countries. Washington DC: World Bank.

$\underline{\text { Journals }}$

Jambeck, J. R., Geyer, R., Wilcox, C., Siegler, T. R., Perryman, M., Andrady, A., ... Narayan, R. (2015). Plastic waste inputs from land into the ocean. Science, 347(6223), 768-771. Retrieved from https://doi.org/10.1126/science. 1260352

Suradinata, E. (2011). Geopolitik dan Geostrategi Dalam Mewujudkan Integritas Negara Kesatuan Republik Indonesia. Jurnal Ketahanan Nasional, 6(2), 80-81. Retrieved from https://doi.org/10.22146/jkn.22056

\section{$\underline{\text { Reports }}$}

Coral Triangle Initiative on Coral Reefs, Fisheries and Food Security. (2009). Regional Plan of Action. Manado: Coral Triangle Initiatives.

Coral Triangle Initiative On Coral Reefs, Fisheries, and Food Security. (2015, January 15). The 7th Senior Official Meeting. Retrieved June 15, 2019, from http://nccctiindonesia.kkp.go.id/?p=340

\section{Internet Sources}

Asian Development Bank. (2014). State of the Coral Triangle: Indonesia. Retrieved from https://www.adb.org/sites/default/files/publication/42409/state-coraltriangle-indonesia.pdf

Badan Informasi Geospasial. (n.d.). BIG. Retrieved October 12, 2018, from http://www.big.go.id/berita-surta/show/rujukan-nasional-data-kewilayahan-luasnkri-8-3-juta-kilometer-persegi

Badan Pusat Statistik. (2014, September 8). Nilai Ekspor Menurut Negara Tujuan Utama. Retrieved June 15, 2019, from

https://www.bps.go.id/statictable/2014/09/08/1010/nilai-ekspor-menurut-negaratujuan-utama-nilai-fob-juta-us-2000-2016.html

Burke, L., Reytar, K., Spalding, M., \& Perry, A. (2011). Reefs at Risk Revisited. Retrieved June 15, 2019, from http://pdf.wri.org/reefs at risk revisited.pdf

The Central Mapping Agency of the Government of the Philippines. (n.d.). About Philippines. Retrieved June 15, 2019, from

http://www.namria.gov.ph/projects.aspx\#pgp 
FAO by United Nations. (2018). The State of World Fisheries and Aquaculture 2018 - Meeting the sustainable development goals. Retrieved from http://www.fao.org/3/i9540en/I9540EN.pdf

Kementerian Kelautan dan Perikanan. (2012). Kebijakan Ekonomi Kelautan Dengan Model Ekonomi Biru. Retrieved from Sekretarian Jenderal Satuan Dewan Kerja Kelautan Indonesia website: http://perpustakaan.bappenas.go.id/lontar/file?file=digital/143663\%5B Konten \%5D-Konten\%20D125.pdf

Kementerian Luar Negeri Republik Indonesia. (2016). Wapres Jusuf Kalla Ajak Masyarakat Dunia Kembangkan Ekonomi Biru dan Perangi Kejahatan Laut. Retrieved June 15, 2019, from https://www.kemlu.go.id/id/berita/siaranpers/Pages/Wapres-Jusuf-Kalla-Ajak-Masyarakat-Dunia-Kembangkan-EkonomiBiru-dan-Perangi-Kejahatan-Laut-.aspx

Kementerian Perdagangan Republik Indonesia. (2014). Perkembangan Perdagangan Indonesia - Filipina Periode Januari-April 2014. Retrieved from Kementerian Perdagangan Republik Indonesia website:

http://www.kemendag.go.id/files/pdf/2015/01/13/report-1421128928.pdf

Kementerian Perdagangan RI. (2017). Konektivitas Laut Bitung-Davao Picu Peningkatan Ekspor ke Filipina. Retrieved from Biro Hubungan Masyarakat Kementerian Perdagangan RI website:

http://www.kemendag.go.id/files/pdf/2017/08/17/konektivitas-laut-bitung-davaopicu-peningkatan-ekspor-ke-filipina-id0-1502932237.pdf

Kementerian Perhubungan Republik Indonesia. (2017, April 28). Deklarasi Bersama Ditandatangani, Ro-Ro Davao Bitung Mulai Operasi 30 April 2017.

Retrieved June 15, 2019, from http://www.dephub.go.id/post/read/deklarasibersama-ditandatangani,-ro-ro-davao-bitung-mulai-operasi-30-april-2017

Kementerian Perhubungan Republik Indonesia. (2017, August 4). BIMP EAGA Sea Lingkages Working Group: Indonesia Dukung Pembangunan Ekonomi di Gerbang Timur Indonesia. Retrieved June 15, 2019, from http://hubla.dephub.go.id/berita/Pages/BIMP-EAGA-Sea-Lingkages-Working-GroupIndonesia-dukung-pembangunan-ekonomi--di-gerbang-timur-indonesia-.aspx

Kementerian Perhubungan Republik Indonesia. (2018, March 2). Empat Puluh Persen Jalur Perdagangan Dunia Melewati Indonesia. Retrieved December 30, 2018, from http://dephub.go.id/post/read/empat-puluh-persen-jalur-perdagangan-duniamelewati-indonesia

Kementrian Luar Negeri Republik Indonesia. (2014, May 23). Peran Aktor Nonnegara Dalam Kebijakan Luar Negeri Untuk Mendukung Pencapaian Kepentingan Nasional RI. Retrieved December 20, 2018, from https://www.kemlu.go.id/id/berita/siaran-pers/Pages/Peran-Aktor-Non-negaradalam-Kebijakan-Luar-Negeri-untuk-Mendukung-Pencapaian-Kepentingan-NasionalR.aspx 
Kompas. (2014, August 14). Potensi Kelautan Indonesia Mencapai 171 Miliar Dollar AS. Retrieved December 15, 2018, from

https://ekonomi.kompas.com/read/2014/08/14/101133026/Potensi.Kelautan.Indon esia.Mencapai.171.Miliar.Dollar.AS

Ministry of Foreign Affair of the Republic of Indonesia. (2017). Joint Declaration by The Government of Republic of Indonesia and The Government of Republic of The Philippines on Sea Connectivity Between Davao/General Santos, Southern Mindanao and Bitung, North Sulawesi. Retrieved from Ministry of Foreign Affair of the Republic of Indonesia website:

http://treaty.kemlu.go.id/apisearch/pdf?filename=PHL-2017-0116.pdf

National Geographic Indonesia. (2017, October 23). Indonesia Siapkan Dana Rp13,4 Triliun untuk Bersihkan Sampah Plastik di Laut. Retrieved June 15, 2019, from http://nationalgeographic.grid.id/read/13308467/indonesia-siapkan-danarp13-4-triliun-untuk-bersihkan-sampah-plastik-di-laut?page=all

Organisation for Economic Cooperation and Development. (2016). The Ocean Economy in 2030. Retrieved from https://doi.org/10.1787/9789264251724-en

Sekretariat Kabinet Republik Indonesia. (2017, March 1). Presiden Jokowi Teken Perpres Kebijakan Kelautan Indonesia. Retrieved December 9, 2018, from http://setkab.go.id/presiden-jokowi-teken-perpres-kebijakan-kelautan-indonesia/

Sekretariat Kabinet Republik Indonesia. (2017, April 30). Luncurkan Rute Ro-Ro Davao-Bitung, Presiden Jokowi: Pelayaran Dari 5 Minggu Jadi 2,5 Hari. Retrieved June 15, 2019, from http://setkab.go.id/luncurkan-rute-ro-ro-davaobitung-presiden-jokowi-pelayaran-dari-5-minggu-jadi-25-hari/

Tejano, R. (2017). Mindanao-North Sulawesi, Indonesia Sea Route. Retrieved June 15, 2019, from http://minda.gov.ph/news/64-mindanao-northsulawesi-indonesia-sea-route

U.S. Department of State. (2006, June 8). The Essential Role of Non-Governmental Organizations in the Development of Democracy. Retrieved June 15, 2019, from https://2001-2009.state.gov/g/drl/rls/rm/2006/68658.htm

United Nations Conference on Trade and Development. (2015). Review of Maritime Transport 2015. Retrieved from United Nations website:

https://unctad.org/en/PublicationsLibrary/rmt2015 en.pdf

United Nations Environment Programme and GRID-Arendal. (2016). Marine Litter Vital Graphics (Nairobi and Arendal. Retrieved from https://wedocs.unep.org/bitstream/handle/20.500.11822/9798/Marine litter Vital graphics-2016MarineLitterVG.pdf.pdf?isAllowed=y\&sequence $=3$

World Bank. (2016). Toward a Blue Economy: A Promise for Sustainable Growth in the Caribbean. Retrieved from 
http://documents.worldbank.org/curated/en/965641473449861013/pdf/AUS16344 -REVISED-v1-BlueEconomy-FullReport-Oct3.pdf

World Wide Fund for Nature. (2015). Principles for a Sustainable Blue Economy. Retrieved from https://www.wwf.se/source.php?id=1605623 